\section{Institutional logic and scholars' reactions to performance measurement in universities}

\section{Performance measurement in universities}

Kirsi-Mari Kallio

Turku School of Economics, Turku, Finland and

Department of Accounting and Logistics, Linnaeus University, Växjö, Sweden

Tomi J. Kallio

Turku School of Economics, Turku, Finland and Department of Organization and Leadership, Linnaeus University, Växjö, Sweden

Giuseppe Grossi

Nord University, Bodø, Norway and

Faculty of Business, Kristianstad University, Kristianstad, Sweden, and

Janne Engblom

Turku School of Economics, Turku, Finland
Received 9 March 2018

Revised 6 March 2020

15 October 2020

4 March 2021

16 March 2021

Accepted 17 March 2021

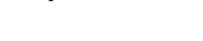

\begin{abstract}
Purpose - Employing institutional logic and institutional work as its theoretical framework, this study analyzes scholars' reactions to performance measurement systems in academia.

Design/methodology/approach - Large datasets were collected over time, combining both quantitative and qualitative elements. The data were gathered from a two-wave survey in 2010 (966 respondents) and 2015 (672 respondents), conducted among scholars performing teaching- and research-oriented tasks in three Finnish universities.

Findings - The analysis showed statistically significant changes over time in the ways that the respondents were positioned in three major groups influenced by different institutional logics. This study contributes to the international debate on institutional change in universities by showing that in Finnish universities, emerging business logics and existing professional logics can co-exist and be blended among a growing group of academics. The analysis of qualitative open-ended answers suggests that performance measurement systems have led to changes in institutional logic, which have influenced the scholars participating in institutional work at the microlevel in academia.

Social implications - While most scholars remain critical of performance measurement systems in universities, the fact that many academics are adapting to performance measurement systems highlights significant changes that are generally occurring in academia.

Originality/value - While most extant studies have focused on field- and organizational-level analyses, this study focuses on understanding how the adoption of performance measurement systems affects institutional logic and institutional work at the microlevel. Moreover, the study's cross-sectional research setting increases society's understanding of institutional evolution in academia.
\end{abstract}

Keywords Institutional logics, Institutional work, Performance measurement, Universities, Hybridity, Academic work

Paper type Research paper

(C) Kirsi-Mari Kallio, Tomi J. Kallio, Giuseppe Grossi and Janne Engblom. Published by Emerald Publishing Limited. This article is published under the Creative Commons Attribution (CC BY 4.0) licence. Anyone may reproduce, distribute, translate and create derivative works of this article (for both commercial and non-commercial purposes), subject to full attribution to the original publication and authors. The full terms of this licence may be seen at http://creativecommons.org/licences/by/4.0/ legalcode 


\section{AAAJ}

34,9

136

\section{Introduction}

Over the last 30 years, institutional and socioeconomic development and globalization have played crucial roles in the changes observed in the higher education sector. These changes have affected aspects such as governance (Boitier and Rivière, 2013), accountability (Narayan et al., 2017), reputation (Suomi et al., 2014), higher education export (Guthrie et al., 2014), organization, funding, management (Tucker and Parker, 2020), budgeting (Lepori and Montauti, 2020; Mkasiwa, 2020), accounting systems (Conrath-Hargreaves and Wüstemann, 2019; Moll and Hoque, 2011), research assessment (Martin-Sardesai et al., 2017a), as well as universities' academic and social legitimacy (Gebreiter and Hidayah, 2019). Previous studies have also shown clear changes occurring in the performance measurement (PM) of universities. Among other topics, scholars have studied the assessment of academic performance (Argento et al., 2020), the use of key performance indicators (Guthrie and Neumann, 2007), research management (Agyemang and Broadbent, 2015), steering (Boitier and Rivière, 2013), and the measurement and evaluation of institutional and individual performance (Dobija et al., 2019; Kallio and Kallio, 2014; Ter Bogt and Scapens, 2012; Englund and Gerdin, 2019; Chatterjee et al., 2020; Martin-Sardesai et al., 2020; O'Connell et al., 2020a). A common factor in all these studies seems to be the transition in the studied organizations' institutional logic (IL) (Grossi et al., 2020a).

Universities are model examples of complex, loosely coupled and heterogeneous organizations (Boitier and Rivière, 2013). Universities' operational (micro)-level activities have been traditionally coordinated based on values and norms determined by professional associations that are "commonly understood as agents of reproduction rather than of change" (Greenwood et al., 2002, p. 73). Consequently, formal management has a limited ability to control - and change - the operational-level work of university organizations. Therefore, although universities are increasingly affected at both the field and the organizational levels by competing ILs (Grossi et al., 2020a), scholars at the microlevel have long been committed to traditional professional logic. Nonetheless, recent empirical studies have also indicated changes at the microlevel in academia (see Kallio et al., 2016, 2020). In line with the recent developments, universities in the Nordic countries have faced increasing competition for students, researchers, and resources, and they are now managed using different PM tools (Kallio et al., 2016, 2017).

Most recently, there has been considerable interest in linking microlevel and macrolevel perspectives in the IL context. However, "much more attention has been given to how institutional forces dictate individual behaviour than to how microlevel activities affect the nature of these forces"; therefore, "[m]ore work is needed to unpack how local actors mediate institutional demands and the requirements of day-to-day organizational activity" (McPherson and Sauder, 2013, p. 166). In this study, we help close this research gap. We adopt the IL and institutional work (IW) perspectives in analyzing how PM adoption and application in Finnish universities have affected university workers and how they mediate new performance-oriented institutional demands by reporting academics' voices and views. The research questions are as follows:

(1) Do scholars experience a steering effect due to PM, and do they perceive PM as increasing work efficiency in academia?

(2) How does the introduction of PM practices affect IL at the microlevel of academia, and how does scholars' work mediate the performance-oriented demands?

Our study is based on cross-sectional data collected over time, which has been suggested as particularly useful for IL research (Townley, 1997). A two-wave survey was conducted in 2010 and 2015 among 12 departments in three universities in Finland. The analysis indicates a change over time in academic workers' stance in relation to PM. This change is further 
perceived as a manifestation of how the local actor level in academia interacts with the macrolevel IL. We attempt to elucidate institutional evolution (cf. Dansou and Langley, 2012) in academia. Moreover, we demonstrate the microlevel-macrolevel interaction as analyzed through the theoretical lenses of IL and IW. We present the academics' responses to the performance-oriented demands imposed on them by dividing the academics into groups. The groups where the majority of the academics belong are labeled as Humboldtians, Performance Managed, and Critical Adaptors.

We have organized this article as follows. After the introduction in the Background section, we introduce the Finnish PM system. We then present the theoretical background and provide a synopsis of studies addressing the changing IL and IW in academia. In the Methods section, we describe the research data and the logic of our empirical analysis. Next, we introduce the four identified clusters of respondents and discuss the changes in the relative sizes of these clusters from 2010 to 2015. Subsequently, we attempt to theoretically understand the indications of the changes in the clusters from the perspectives of IL and IW in academia by using the academics' voices. We end this paper with conclusions and suggestions for further research.

\section{Background: university performance measurement in Finland}

Our study focuses on Finland, which follows the so-called centralized higher education policy, meaning that education is regulated via unified national legislation. All 13 universities in Finland are publicly funded based on detailed performance criteria determined in budgetary negotiations between each university and the Ministry of Education and Culture. The ministry renewed its funding scheme and PM system completely in 2010. The new performance criteria are mostly quantitative, emphasizing the universities' outputs, including the number of degrees produced, study credits, publications, and the amount of external funding (e.g., Kallio et al., 2017). In the new funding scheme, the emphasis on output has become more dominant. Therefore, the model emphasizes each university management's autonomy in finding the means for securing its output. The system is controlled by outcomes and ex post monitoring, not by budgeted expenses and ex ante planning, as previously. The ministry's essential purpose in implementing PM was to increase university effectiveness and efficiency, as well as elevate their positions in international rankings (see Kallio et al., 2016). With the state budget law's renewal in 2010, Finnish universities also adopted a nationwide unified pay scheme with consistent performance criteria and preset salary levels [1].

The Ministry of Education and Culture regulates the number of universities that can exist in Finland and the number of degrees they offer. Moreover, funding for Finnish universities is dependent on the state [2]. Thus, the funding scheme is designed to incentivize universities to operate in a way that maximizes the number of degrees issued and pushes their students to graduate in a shorter amount of time. The basic funding allocation in Finland can be considered the most performance-driven among the European Union (EU) countries (Kallunki et al., 2019). The PM system's execution goes all the way to the individual university employee level at least implicitly, as performance is monitored and reported rigorously via a performance measurement and incentive system, a pay scheme, and quality assurance policies (Kallio and Kallio, 2014).

In the Finnish model, universities' basic funding is tied to objectives, divided into three categories: (1) objectives of education and science policy; (2) the quality, effectiveness, and internationalization of education; and (3) the quality, effectiveness, and internationalization of research. Under these categories, funding associated with different indicators is further divided according to the number of degrees granted, the number of students completing 55 study credits per year, student feedback, the percentage of graduates employed, the number 
AAAJ 34,9 of publications, the amount of external funding received, and the number of degrees earned by foreigners and foreign research and teaching staff (Järvenpää et al., 2021).

The Finnish case is interesting, since the reforms and adopted methods and criteria echo similar changes in almost all Western countries (Parker, 2014). The United Kingdom (UK) is the forerunner in the degree to which its PM reforms have been implemented (e.g., Agyemang and Broadbent, 2015). Australia is one of the early adopters (see Christopher, 2012; Churchman, 2002). Recently, this modernization and spread of business logic have also touched the former Eastern-bloc countries (Czarniawska and Genell, 2002) and Asia (Upping and Oliver, 2012). The purpose of universities has become increasingly central to national innovation policies. Parker (2012, p. 248) states, "[U]niversities have become not only educational institutions in their own right, but vital components of government and corporate education export programs as well as national economic drivers." He adds that the new style of university management philosophy "is pursued via output focused accountability and controls, and market based competition" (Parker, 2012, p. 248). Thus, universities in different countries increasingly compete with one another based on certain performance criteria, various university rankings, and so on (Kallio et al., 2020).

Due to the centralized model under which Finnish universities operate, all the national reforms touch each university directly. Additionally, the fact that higher education is regulated via unified national legislation and the basic funding for all Finnish universities comes from the state budget makes Finland an interesting case for studying the effects of PM. Moreover, in contrast to some countries, such as the UK (Gebreiter and Hidayah, 2019), other changes in the organizational environment have not affected university employees' work drastically. For example, Finland has not experienced as rapid a change in foreign student populations as many other European countries have. Although foreign student enrollment has increased, in 2017, only around $10 \%$ of the enrollment comprised students from foreign backgrounds. These elements make Finland optimal for studying the effects of changes that can be traced back to PM reforms.

Although the primary purpose of the PM system introduced by the Ministry of Education and Culture was to redirect the Finnish higher education sector, Kallio et al. (2017) find that individual universities and departments have more or less copied the ministry's PM principles into their internal administration and respective PM systems. Consequently, the field-level centralized PM system now implicitly affects the microlevel and thus, the daily operations of thousands of employees in Finnish universities (Kallio et al., 2017, 2020). PM reform and its indicators have increased stress and created the need for constantly showing results, especially in publishing and attracting external funding (Kallio et al., 2017).

\section{Competing institutional logics and their effects on institutional work in academia} Agendas such as corporatization, marketization, managerialism and modernization (Churchman, 2002; Guthrie and Neumann, 2007; Parker and Guthrie, 2010; Roberts, 2004) were introduced to the university world a few decades ago. The emergence of the judgmental PM (Ter Bogt and Scapens, 2012) and its assessment and evaluation frameworks seem to have interfered with academic work, exposing it to external quantitative targets and metrics (Kallio et al., 2016). Developments originating in the UK - namely reforms embracing market discourse - have been criticized as leading to the commodification of higher education and academic work. Its results are (among others) the separation of research from teaching and an increased surveillance of academic work (Gebreiter and Hidayah, 2019). More recently, and in line with these developments, instruments such as world ranking tables, journal quality listings, and government research assessment evaluation systems, as well as new forms of academic career systems (e.g., Czarniawska and Genell, 2002), have been introduced to universities in the West and beyond. These assessment and evaluation systems stem from a 
managerialist background, embracing business logic and thus creating dilemmas of governance in higher education institutions (Grossi et al., 2020a; Narayan et al., 2017). Prior studies inquiring into these phenomena have found that changes in universities' political, institutional and funding environments increase management's power and diminish academics' autonomy, while forcing universities to compete with other knowledge producers (Kallio et al., 2020; Narayan et al., 2017). In the attempt to make universities more market-oriented, academic work has also been homogenized (Churchman, 2002).

Several recent studies addressing scholarly work in academia have indicated significant changes in how individual researchers' and teachers' performance is evaluated (Grossi et al., 2020b; Kallio and Kallio, 2014; Kallio et al., 2017; Ter Bogt and Scapens, 2012). This line of research exists at the intersection of two broader academic discourses. One addresses new public management (NPM) and PM (e.g., Hood, 1995; Steccolini et al., 2020); the other studies changes in higher education organizations and the academic profession (e.g., Kallio et al., 2020; Martin-Sardesai et al., 2019). Over the last few decades, numerous studies have identified fundamental changes in academia that are typically connected to underlying assumptions concerning the nature of academia in general and how university organizations are managed in particular. Scholars with recent publications in interdisciplinary accounting journals include Gebreiter and Hidayah (2019), Kallio et al. (2020), Lepori and Montanauti (2020), Tucker and Parker (2020), O'Connell et al. (2020b), Conrath-Hargreaves and Wüstemann (2019) and Gebreiter (2021). Scholars have typically recognized and theoretically elaborated on two or more competing logics.

Thornton et al. (2012) name multiple logics (or institutional orders) that may co-exist at the interinstitutional level, including the state, market, corporation, profession, family, religion, and community. There are multiple ways of describing and labeling competing logics in academia. In this study, we refer to the underlying competing logics in universities as traditional professional logic (e.g., Kallio et al., 2016) and new business logic (e.g., Agyemang, 2009). These two logics are derived from the NPM-style reform literature (e.g., Chandler et al., 2002; Martin-Sardesai et al., 2019; Parker, 2011). They comprehensively capture the phenomenon that we are describing, simultaneously allowing us to elaborate on the changes occurring in universities relatively rapidly at the field, organization, and individual levels.

Recently, competing logics have received considerable scholarly interest, with institutional complexity being generally considered a theoretically puzzling topic of research (e.g., Besharov and Smith, 2014). According to Thornton and Ocasio (2008), even if presenting competing logics in scholarly analyses often means either simplifying or exacerbating certain characteristics of the logics, constructing such ideal types and ideal type pairs is useful for the theoretical understanding of the logics. Based on the existing literature, Figure 1 summarizes some essential attributes of competing ILs in academia, especially from our study's perspective - PM in academia.

As illustrated in Figure 1, and from the viewpoint of professional logic, traditional academic identities are perceived as homogeneous and based on collegial identity. From the perspective of business logic, academic identities are regarded as less homogeneous and based on a competitive ethos (Kallio et al., 2016; Christopher, 2012). The traditional conception of academic work has underlined intrinsic motivation and vocation. However, the challenging business logic, mainly derived from NPM, recognizes extrinsic factors as legitimate sources of motivation; rather than a vocation, it views scholarly work as a job like any other (Kallio and Kallio, 2014; McInnis, 2010; Martin-Sardesai et al., 2017b). The mode of behavior under professional logic is understood as deeply value-laden. While scholars' behavior in relation to their surrounding society is expected to be independent, impartial, and neutral, there is a deep value-laden mindset of advancing free science. The traditional understanding of academic work, which underlines academic freedom, has been challenged by business logic, which relies on utilitarian survival. Consequently, while loyalty to one's discipline is viewed to be at
Performance measurement in universities 


\section{AAAJ 34,9}

Attributes related to the logics

Academic identity and ethos

Basic conception of scholarly work

Mode of behavior

Source of legitimacy

Figure 1.

Some essential attributes of competing institutional logics in Finnish academia

\begin{tabular}{|c|c|}
\hline $\begin{array}{l}\text { Professional logic in } \\
\text { academia }\end{array}$ & ness logic in academia \\
\hline Homogeneous; collegial & $\begin{array}{l}\text { Heterogeneous; } \\
\text { competitive }\end{array}$ \\
\hline $\begin{array}{l}\text { Intrinsic motivation; } \\
\text { unlike any other job; } \\
\text { vocation }\end{array}$ & $\begin{array}{l}\text { Extrinsic motivation; a job } \\
\text { among others }\end{array}$ \\
\hline $\begin{array}{l}\text { Valuing free science; } \\
\text { academic freedom; } \\
\text { loyalty to academic } \\
\text { discipline }\end{array}$ & $\begin{array}{l}\text { Producing value for money; } \\
\text { utilitarian survival; loyalty } \\
\text { to employer }\end{array}$ \\
\hline $\begin{array}{l}\text { Internal legitimacy; } \\
\text { accountability to } \\
\text { scientific community and } \\
\text { professional associations }\end{array}$ & $\begin{array}{l}\text { External legitimacy; } \\
\text { accountability to the } \\
\text { ministry and other external } \\
\text { funding bodies }\end{array}$ \\
\hline $\begin{array}{l}\text { Quality determined by } \\
\text { academic community }\end{array}$ & $\begin{array}{l}\text { Quality determined by } \\
\text { funders, working life, and } \\
\text { society; quantification of } \\
\text { quality }\end{array}$ \\
\hline $\begin{array}{l}\text { Developmental; } \\
\text { qualitative; future- } \\
\text { oriented }\end{array}$ & $\begin{array}{l}\text { Judgmental; quantitative; } \\
\text { focus on past outputs }\end{array}$ \\
\hline Long-term & Short-term \\
\hline
\end{tabular}

least as important as loyalty to one's current organization in professional logic, business logic emphasizes the latter type of loyalty (Gumport, 2000).

The source of the legitimacy of scholarly work has traditionally been traced to one's scientific community and professional associations (Greenwood et al., 2002). Therefore, the traditional type of legitimacy can be considered internal in the sense that it is derived from the academic profession's principles, and scholars are accountable for their community. However, business logic is managerially oriented and considers external funders' policies crucial for the legitimacy of scholarly work. Consequently, universities' strategies and performance indicators are mostly designed for external accountability (Gumport, 2000; Kallio et al., 2017; Townley, 1997). Similarly, whereas professional logic leans on the academic community when determining the quality of universities' essential outputs (e.g., teaching and research), business logic relies on quality assurance as determined outside academia, including funders, the government, and the business world. Moreover, business logic tends to approach quality in measurable terms and thus quantifies quality (Kallio et al., 2017). Consequently, the PM of business logic is judgmental and mostly quantitative, focusing on past performance, in contrast to the developmental and more future-oriented PM practices in traditional professional logic (Ter Bogt and Scapens, 2012; Townley, 1997). Within the business logic, PM practices also promote short-term orientation in the evaluation of research projects and results (see, e.g., Kallio et al., 2017). 
As a theory, IL is especially useful in explaining institutional change and the way that field-level institutions affect organizational-level strategies and practices (e.g., Thornton et al., 2005; Thornton and Ocasio, 1999). However, Thornton et al. (2012) state that the research addressing IL does not adequately explore how different logics are used "on the ground" in the actors' day-to-day behaviors and experiences. Thus, neo-institutional theory has moved beyond traditional isomorphism and decoupling to consider heterogeneity, accounting for actors and identifying practice diversity (Lounsbury, 2008). This is in line with Battilana's (2006) suggestion that besides the societal and the organizational levels of analysis, individuals' role must be included when theorizing about institutional change.

It follows that competing ILs should be integrated with other theoretical approaches because this perspective does not address the micro-dynamics involved in (re-)constructing PM, based on the implications of everyday practices. Consequently, IL can be combined with IW (cf. Gawer and Phillips, 2013) to investigate how real PM practices are translated in the university context. Central to the notion of IW "are the intentions of actors on the one hand and the consequences of their work on the other hand" (Zilber, 2013, p. 87). IW involves physical and mental efforts, aimed at affecting an institution or a set of institutions (Lawrence et al., 2011). IW investigates internal dynamics and the interactive nature of actors' relations to IL and focuses on the actions and the interactions among professionals working under ambiguous conditions (Czarniawska, 2009) [3].

According to Lawrence et al. (2011, p. 57), the "construct of institutional work de-focalizes agency by shifting attention away from dramatic actions of the heroic entrepreneur to the small worlds of institutional resistance and maintenance in which institutionalization and institutional change are enacted in the everyday setting by individuals and groups who reproduce their roles, rites, and rituals at the same time that they challenge, modify, and disrupt them." Lawrence et al. (2009) suggest three general forms of IW, respectively creating, maintaining, and disrupting institutions. Thus far, IW that creates institutions has received more scholarly attention than IW that maintains or disrupts institutions (Dansou and Langley, 2012; Lawrence et al., 2009). Dansou and Langley (2012) note that although the three types of IW are typically considered separate forms, they may also be perceived as complementary elements of an overall institutional evolution.

A particularly challenging aspect in the study of IW is the actors' intentionality (Lawrence et al., 2009). The intentionality or purposefulness of action is empirically challenging to capture (Zilber, 2013). Thus, one can question how to distinguish "ordinary work" from "institutional work" - given that IW is described as often "nearly invisible" and "mundane," even from the perspective of the scholars studying it (see Dansou and Langley, 2012; Lawrence et al., 2009). Consequently, Lawrence et al. (2013) state that while the reflective purposefulness of action was the defining characteristic of IW in their studies (e.g., Lawrence and Suddaby, 2006; Lawrence et al., 2009), in more current research, some scholars have begun to include any action as an indication of IW (Modell, 2020). Given that IW may even appear as ordinary day-to-day activity from the perspective of ethnographic research, unsurprisingly, the methods relying on retrospective approaches have limits regarding its depiction. Therefore, Dansou and Langley (2012, p. 506) suggest that it is also justifiable to try to understand IW in contexts "where intentionality appears to be less pronounced." Similarly, Suddaby et al. (2015) recognize that the agency that creates IW is not always intentional.

The general lack of focus on microlevel activities in the concept of IW in research using neo-institutional theory is also present in studies of higher education (Cai and Mehari, 2015; Aleksandrov, 2020). Accordingly, while the consequences of changes in the field and the organizational levels from the university personnel's viewpoint have been reported (Kallio and Kallio, 2014; Kallio et al., 2016), the extant literature typically reflects macrolevel phenomena, such as field-level changes' effects on higher education organizations as a whole (see Boitier and Rivière, 2013; Gumport, 2000; Modell, 2005). Thus, the extant studies' 
AAAJ

34,9

142

perspective is mostly from macro to micro, typically reporting how university workers experience and react to changes in their management systems and practices, organizations and the operational environment in general. The research conducted from the opposite perspective, that is, how microlevel activities affect macrolevel ones, is much more sporadic (McPherson and Sauder, 2013; Aleksandrov, 2020). Therefore, much less knowledge is available on how scholars affect their organizations and influence IL through their actions and behaviors. In the higher education context, the IW perspective may offer useful complementary insights to account for conflicts in and resistance to higher education reforms because some key actors (i.e., scholars) may try to retain the old institutional framework, while new ILs are introduced by the reforms (Cai and Mehari, 2015). After briefly describing the research data and analysis, in the subsequent sections, we focus on PM reforms' effects on IL (from professional to hybrid logic) and IW (individual workers' intentions, on one hand, and the effects on their work, on the other hand) in academia.

\section{Research data and methods}

This study is based on a longitudinal analysis of a large Internet-based survey conducted in two waves (2010 and 2015) among employees in three Finnish universities. For each university, four departments - economics and business, mathematics and natural sciences, humanities and education sciences - were included in the survey. The universities and the faculties were chosen as a selective sample to represent Finnish universities, since they are located in different geographical regions in Finland and all have the same faculty structure. The first two authors developed the survey instrument, based on their understanding of the new university legislation, enacted in 2010. The survey was sent to every employee performing research- and/or teaching-oriented tasks in 12 departments [4]. Before the first data collection wave in 2010, the survey was tested on three professors and revised. It was then piloted on 172 employees in five universities and revised again. The extensive testing and revision aimed to ensure that the questions and terminology were intelligible and appropriate for respondents from different backgrounds. Conducted in Finnish, the survey contained multiple-choice questions and Likert-type scale statements to collect quantitative data, as well as open questions to collect qualitative data. All questions and statements either implicitly or explicitly addressed PM [5].

In 2010, the survey had 966 respondents, with a 33.6\% response rate. In 2015, it had 672 respondents, with a $22.5 \%$ response rate. The non-response analysis by university, department, and field of science revealed no essential systematic loss [6]. The response rates varied to some extent among the individual departments. This should make no difference in the study, as the present analysis is not performed at the department level. Accordingly, the data collected from the different universities, departments, and fields of science are used as a whole, while the essential comparison is longitudinal, comparing the 2010 and the 2015 data. As shown in (Table A2), the two datasets do not have much difference in the respondents' characteristics.

Both survey waves' response rates can be considered good or sufficient, representing the average response rates in survey studies (e.g., Baruch and Holton, 2008; Shih and Fan, 2009). The missing values for both the multiple-choice questions and Likert-type scale statements were relatively small for both the 2010 and the 2015 data. Moreover, the relatively few blank answers to the open survey questions indicate the respondents' diligent answers.

To answer the research questions, it was necessary to first understand where the respondents stood concerning PM in academia. After a thorough statistical analysis, we chose two particularly interesting Likert-scale statements as variables. The statement "Performance measurement increases work efficiency in universities" was used as a variable to indicate whether the respondents perceived PM in universities as having the effect aimed 
for by the Ministry of Education and Culture and the individual universities and departments - increased work efficiency. Another Likert-scale statement, "Performance measurement steers my work," was used as a variable to indicate whether the respondents also experienced the steering effect of PM in their work. We used these statements to build groups ("clusters" in this study) of respondents. Cross-tabulations were used to build joint distributions of two Likert-scale variables describing the clusters.

In addition to the quantitative data used to form the respondent clusters, qualitative data were obtained. The qualitative analysis was based on the open-ended question, "How does performance measurement affect your work motivation?”, which typically elicited long, multifaceted answers.

While the chosen open-ended question asks about PM's effect on the respondents' motivation, the respondents also typically reflected on their perceptions, reactions, and behaviors caused by PM. Therefore, the responses to this question provided rich and multifaceted information that helped increase our understanding of the differences in mindsets among the respondent clusters. The quotes selected for presentation in the data analysis depict the respondents' typical reasoning for their responses. The qualitative data also helped us identify types of IL and understand the IW involved. We coded the qualitative data in a data-driven way and went through the responses according to the clusters and coding themes emerging from them.

As complex phenomena such as IL are typically difficult to capture empirically (Zilber, 2013), interpretation is needed in the analysis of qualitative data (Graneheim and Lundman, 2004). We applied qualitative content analysis to recognize the competing ILs and different types of IW in the data. Using Hsieh and Shannon's (2005) terminology, we applied directed content analysis. This means that we used prior research and theory relating to IL and IW as an initial framework to recognize and name different logics in the data. We focused on both manifest and latent content (Graneheim and Lundman, 2004). Accordingly, in some cases, the concepts related to IL and IW were verbally mentioned, thus visible and obvious (manifest content). In other cases, they were implicit, entailing more interpretation to understand the "underlying meaning of the text" (latent content; Graneheim and Lundman, 2004, p. 106).

As suggested above, the reflective purposefulness of IW is difficult to capture empirically (Zilber, 2013). In this study, we analyzed the IL and the IW by respondent cluster, since they exemplified some interesting differences in ILs [7]. We also used extracts from the answers to the open-ended question to illustrate the qualitative data and our interpretations. The extracts have been translated into English by the first two authors.

\section{Results: clusters of scholars}

The two selected statements were used to build a $5 \times 5$ cross-tabulation for the years 2010 and 2015 (Table A2). Next, the "completely agree" and "mostly agree" answers, on one hand, and the "completely disagree" and "mostly disagree" answers, on the other hand, were merged to form dummy variables. The dummy variables were used to sort the data into mutually exclusive categories and thus delineate the respondent clusters (see Table 1). The respondents who answered "do not agree or disagree" to either of the statements used as variables to build the clusters are not included in the percentage shares in Table 1.

Table 1 shows the percentage of respondents who either "agreed" or "disagreed" with both dichotomized statements - "Performance measurement increases work efficiency in universities" and "Performance measurement steers my work" - for both the 2010 and the 2015 datasets. From the original responses, four clusters (agree-agree, agree-disagree, disagree-agree, and disagree-disagree) were built and subsequently labeled. In Table 1, the percentages in the cells are presented as percentages of the total data in 2010 (above) and 2015 (below). The row and column distributions are also presented to provide the 
AAAJ
34,9

\section{4}

Table 1.

Dichotomized statements

\begin{tabular}{|c|c|c|c|}
\hline \multirow[b]{2}{*}{$\begin{array}{r}\text { PM steers } \\
\text { my work }\end{array}$} & \multicolumn{2}{|c|}{$\begin{array}{l}\text { PM increases work } \\
\text { efficiency in universities }\end{array}$} & \multirow[b]{2}{*}{$\begin{array}{r}\text { Total } \\
(\%)\end{array}$} \\
\hline & Agree (\%) & $\begin{array}{l}\text { Disagree } \\
(\%)\end{array}$ & \\
\hline \multirow[t]{2}{*}{ Agree } & 19.70 & 17.02 & 36.72 \\
\hline & 22.46 & 27.09 & 49.55 \\
\hline \multirow[t]{2}{*}{ Disagree } & 5.03 & 58.24 & 63.27 \\
\hline & 3.74 & 46.69 & 50.43 \\
\hline \multirow[t]{2}{*}{ Total } & 24.73 & 75.27 & \\
\hline & 26.20 & 73.78 & \\
\hline
\end{tabular}

2010 percentages above and 2015 percentages below

distributions of both statements separately. We have labeled the four individual clusters, based on the academic workers' attitudes toward PM, as "Performance Managed," "Critical Adaptors," "Mixed" and "Humboldtians" (Figure 2). These labels were iteratively developed during the data analysis as a consequence of the authors' interpretation of the open-ended data. In labeling the clusters, we attempt to capture the stereotypes they represent. Our purpose is not to reflect any preference but to concisely articulate the central attributes of each cluster.

Eliminating the Mixed cluster from further analysis (as explained in more detail below) left 967 responses to the selected open-ended question. The 2010 and the 2015 data from the three remaining clusters respectively contained 179 and 106 empty or extremely short answers.

Figure 2.

Intentions of academic workers toward PM
PM increases work efficiency in universities

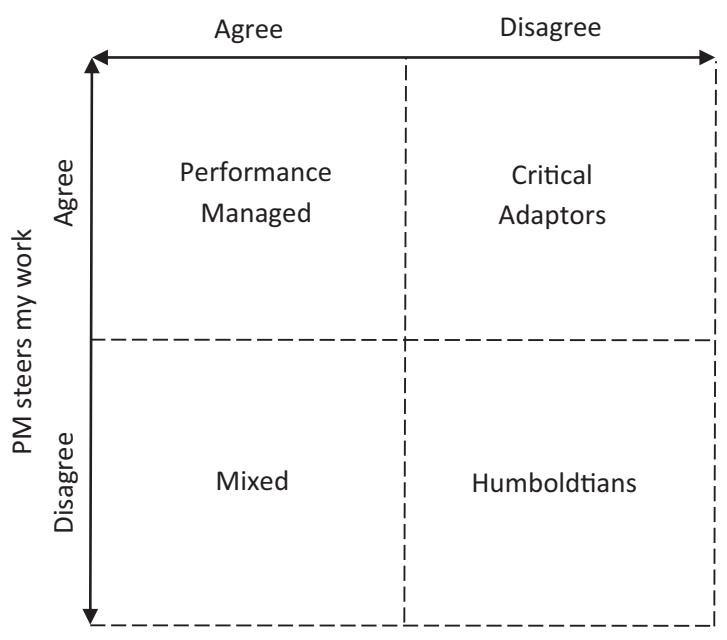


After these answers, 682 remained [8]. Below, we analyze the clusters in more detail using the open-ended data, starting with the largest cluster.

Humboldtians formed the largest respondent cluster in both the 2010 and the 2015 datasets. This cluster's respondents disagreed with both the variables. They neither believed that PM would increase work efficiency in universities nor thought that PM would have a steering effect on their work. They were labeled Humboldtians to represent the assumption that regardless of the implementation of the PM system, they seemed to have kept Wilhelm von Humboldt's romantic ideal of science in the early 19th century. They experienced something other than PM as steering their work. The following extracts (see Table 2) illustrate the respondents of this cluster's typical answers to the open question, "How does performance measurement affect your work motivation?"

The Humboldtian cluster generally had two types of responses. On one hand, some Humboldtians stated that PM did not affect their personal motivation even if PM had negative effects on scholarly work in academia in general. In a sense, they continued their work regardless of PM and its negative effects. On the other hand, most Humboldtians reported a decrease in their work motivation. Humboldtians can be understood as representatives of the traditional academic profession who typically feel that intrinsic motivation and vocation rather than extrinsic motivation should steer scholarly work.

Humboldtians made up the largest cluster in both 2010 and 2015. Moreover, in both years, the largest individual cell of the whole data was the extremist cell in the Humboldtian cluster, indicating strict disagreement (“completely disagree") with both statements (see Appendix 1). However, this individual cell's percentage clearly dropped from 2010 to 2015 . At the same time, the total share of the Humboldtian cluster dropped $11.55 \%$ points in the five-year period

Performance measurement has increased the amount of unnecessary work, which takes time from the actual productive work. I expect that performance measurement will decrease the quality of [bachelor's, master's, and doctoral] degrees and teaching as the indicators currently measure the number of degrees and credits. (2010) My work motivation has been decreasing, and while I used to do a lot of work during the weekends and evenings, now I only do what is absolutely necessary. As I see it, the politicians have raped the universities with the mandate of the business world, and I feel like I'm living in an occupied territory. I feel that the government is the greatest enemy of free science. (2010)

The effect is absolutely negative; in the long run, the effects of this plutocratic rule will be devastating both for individuals and society. (2010)

It stresses me out. I'm a person of high intrinsic motivation and I always do my best, especially in teaching. However, the constant surveillance, monitoring, and counting of outputs are really demotivating and unpleasant. (2015)

It lowers it [work motivation] considerably. Performance measurement is ridiculous and unfair, and a scholar who is trained to think critically cannot swallow it. It doesn't suit academia at all. In science, the motivation originates completely from somewhere else than from the infantile practices [copied from] the business world. (2015)

It either has no effect at all because I don't care about it or the effect is solely negative as this "performance measurement" is not interested in the content and quality of research but just in easily measurable mattersmeaning, in practice, the number of publications. (2015)

Well, not in any way; one's own intrinsic motivation is always more important and a more sustainable source of motivation than external sanctions and monitoring are. (2015)

Extremely negatively. Everybody knows that the "performance measurement" is idiotic. It makes me angry to do unnecessary work [due to PM]. It leads to a situation where opportunistic people advance in their careers and those who are gifted and take their work seriously will suffer. (2015)

There's a minor effect. Developing one's work in both teaching and research is driven by intrinsic motivation and a desire to develop and advance one's field of science. (2015)

It does no't improve work motivation when everything is being monitored. The academic freedom that once felt compelling and has been a privilege for those in the academic world has vanished almost entirely. (2015)
Performance measurement in universities
Table 2.

Examples of typical quotes from Humboldtians 
AAAJ 34,9

146

between the datasets (see Table 1). This change was found to be statistically significant at the 0.001 level.

The cluster opposite to Humboldtians was labeled Performance Managed. The respondents in this cluster agreed with both statements; they believed that PM increased work efficiency in universities and had a steering effect on their work. As indicated by the label, this group of scholars seemed to obey the PM principles. However, this cluster's respondents were typically less extreme in their opinions compared with Humboldtians, as can be seen from the cell counts in Appendix. The Performance Managed cluster's tendency to be less fervent in their opinions can also be detected from their typical responses to the question, "How does performance measurement affect your work motivation?" (see Table 3).

Compared with Humboldtians, the Performance Managed cluster's respondents represent a different type of scholar who has adopted a more competitive and instrumental perspective on academic work. This cluster's relative weight increased by 2.76 percentage points from 2010 to 2015 . This change is presently rather small and not statistically significant.

Between 2010 and 2015, the Critical Adaptors cluster gained the most relative and absolute weights. From only being the third largest cluster in 2010 , with a $17.02 \%$ share, in 2015 , the cluster clearly surpassed the Performance Managed cluster and became the second largest overall, with a $27.09 \%$ share. This means that the Critical Adaptors cluster gained as much as 10.07 percentage points in five years. This change is statistically significant at the 0.001 level. The cluster itself shows an interesting mix of Humboldtian and Performance Managed perceptions. This cluster's respondents disagreed with the statement that PM would increase work efficiency in universities. At the same time, they agreed with the statement that PM had a steering effect on their work. While this may seem somewhat contradictory, in the following section, we explain how this type of logic can be considered rational. The cluster was labeled Critical Adaptors because the respondents seemed very critical of the PM system yet played by the rules of the new "PM game." Their typical responses to the open question are illustrated by the extracts provided below (see Table 4).

[P]erformance measurement motivates, but if it is taken to extremes, it starts to be stressful. (2010)

On the one hand, motivation increases because one's accomplishments can affect one's salary, but on the other, constant monitoring and performance enthusiasm are exhausting. (2010)

In my case, performance measurement affects my work motivation positively; if I work more and better, I will receive a better salary, and thus, I am acknowledged for the work I do. (2010)

I see it [PM] as part of the job description; those who fund the operations want to see that the money is well spent. (2010)

Throughout my career, I have always evaluated my achievements and made plans for the coming years.

Performance measurement mostly creates institutional practices and bureaucracy. In that sense, it means only extra work, but then again, it's nice to get feedback about your achievements. In my work, performance measurement reminds me not to waste good manuscripts on forums that do not produce research credits. (2015) [It] increases work motivation. It's good that active and productive people get rewarded. (2015)

On the one hand, it [PM] helps to make it clear how one"s work input should be directed. On the other, it causes pressure and stress. (2015)

In principle, it [PM] inspires one to try to publish in increasingly reputable journals. (2015)

On the one hand, I think it's good that contributions get monitored and that there cannot be free riders among us; to a certain extent, competition improves, for example, the quality of research and teaching. Emphasizing the responsibilities to produce outputs also produces constant pressure and a sense of insufficiency; nothing

Table 3.

Examples of typical quotes from Performance Managed ever seems to be enough. (2015)

No problems. Performance measurement is here to stay, and it just has to be accepted. Of course, for many, extreme competition may destroy work motivation, but in a world of finite resources, performance measurement is fair in principle. (2015) 
The Mixed cluster is the fourth and clearly smallest one in both 2010 (5.03\%) and 2015 $(3.74 \%)$. Its respondents' perceptions can be described as somewhat contradictory. On one hand, they believed that PM would increase work efficiency in universities. On the other hand, they reported that PM had no steering effect on their work; therefore, we labeled them Mixed. While some respondents explicitly stated that PM was not working as it should, the qualitative data analysis suggested no notable systematic logic of argumentation behind the open-ended answers in this cluster. In this sense, this cluster had no "typical" open-ended answer, perhaps excluding the fact that the cluster contained many short answers. In general, these answers tended to be shorter than those provided by the other three clusters' respondents (see Table 5).

The decrease in the Mixed cluster's size from 2010 to 2015 could indicate that as the departments developed their respective PM systems over the five-year period, some respondents who were previously in this cluster migrated to other clusters. Because this cluster is significantly smaller than the other three, and it was not possible to find any clear pattern or logic in its responses, the cluster receives no further attention in the remainder of this study.

I cannot say yet. Perhaps it motivates me to write more, as I have committed to a certain amount of journal articles in my work plan. (2010)

Depending on my superior, sometimes positively and sometimes negatively. Mostly negatively. (2010)

It is a controversial matter. Performance measurement has brought a certain assertiveness, which I think is positive [...]. However, it easily goes a bit too far and turns into a slave driver. The best results in universities come when there's some flexibility and fun in the making. I must admit that in my own case, the sense of flexibility and fun has been lost occasionally. (2010)

Varying - sometimes it motivates, sometimes it discourages. Mostly, it creates pressure. (2010)

I'm highly motivated in my work, but the current system causes some anxiety and feelings of insufficiency because [... ] the things that actually get rewarded [in PM], that is, the research credits [produced mostly by refereed articles] must typically be scraped together during one's "own private time." (2010)

Well, the possibility to increase your salary spurs you to do and try a bit more. However, this causes stress, and if you take on too many things, you just cannot do them properly, and the quality of your work might suffer. However, the genuine interest in your field and the intrinsic will to perform well in your work are much greater sources of motivation than performance measurement is. (2015)

Performance measurement affects my work motivation negatively. The real aim should be doing persistent research. Monitoring and reporting take time and steal the focus from the actual work. These activities also cause stress and create pressure to make one's achievements visible, which increases the possibility of burnout and makes the work feel futile. High-quality research takes time. The yearly evaluation spurs people to publish incomplete studies and doesn't really depict people's real abilities to do research. (2015)

Negatively. Unnecessary stress accumulates on everybody due to the need to collect credits and publish as much as possible so that the wheels keep turning, and the quality should still not be neglected. (2015)

Usually negatively. Narrow indicators direct work to peculiar tracks that have very little to do with any reason. Research, in particular, is based on passion, and these [PM] arrangements do not really support it. (2015)

Table 4.

Examples of typical quotes from Critical Adaptors

No effect. (2010)

Arouses controversy. Makes you question your own motivation every now and then, which is connected to more holistic effects than those measured by the performance indicators. (2010)

Very little. (2010)

Lowered [work motivation from PM] because performance measurement isn't working in the supportive way it should. (2010)

No major effect, although it causes some extra work. (2015)

Merely positively. (2015)

Table 5.

Example quotes from Mixed 
Discussion: institutional logic and work at the microlevel in academia

In the previous section, we answered our first research question and provided some empirical basis for answering our second one. To answer the latter in a theoretically more in-depth way, we now examine our data from the perspective of IL and IW while trying to understand how scholars mediate performance-oriented demands in their work. We recognize three types of IL - professional, business and hybrid - with hybrid logic being a mixture of the first two types' attributes.

Related to the three types of logic, our data analysis also indicates traces of different types of IW. As discussed more closely below, we recognize both maintaining and disruptive work and, to a lesser extent, creating work (Battiana and D'Aunno, 2009; Dansou and Langley, 2012; Lawrence et al., 2009).

According to Pollitt (2013, pp. 347-348), "whilst specific groups within an organization may well be strongly associated with one or another particular logic, it should not be assumed that all members of a group will always think in one way, or, indeed, that individuals will always apply the same species of logic." While our qualitative data analysis confirms Pollitt's (2013) argument that the groups are not completely uniform in their perceptions and rationalities, Humboldtians in particular had almost unanimous responses regarding the effects of PM in academia.

For Humboldtians, PM mostly resulted in a lower quality of teaching and research and a poor working climate, with increased bureaucracy and stress. They hardly saw anything positive in PM; nevertheless, they wanted to work in academia, regardless of the low salary and the declining atmosphere. However, some respondents clearly stated that they had been thinking of abandoning academia because of PM and its side effects. The themes constantly brought up in the Humboldtian responses included collegiality, academic freedom, genuine interest in science and loyalty to one's own discipline, internal legitimacy, intrinsic motivation, and quality determined by the academic community. These attributes are identical to those discussed above as manifestations of traditional professional logic (see Figure 1), and throughout the qualitative data, it becomes clear that Humboldtians as a group lean on traditional professional logic.

In most of the Humboldtians' responses, IW was indirectly visible. For instance, Humboldtians stated that they did not let PM affect their work:

[I think that] a scholar doesn't have to explain his/her work to anybody and he/she may choose his/ her own work methods. When implementing performance measurement, there should be a clear caution so that it won't interfere with work methods/routines, which are different for each individual. Even if minor, constant monitoring or similar behavior implies trespassing on one's territory, which then feels like lurking, and thus, lowers work motivation. (2010)

There's no question that I will meet my output targets, but it's not because of the [PM] incentives. By nature, I'm a civil servant, and I always do my tasks as well as possible regardless of incentives or requirements. (2015)

Performance measurement has no effect on my work motivation. I'm a doctoral student, and my work motivation stems from the great mysteries of natural sciences. (2015)

By refusing to play by or ignoring the PM rules, Humboldtians either explicitly or implicitly fought against the competing business logic. Thus, they aimed to maintain traditional professional logic (Battilana et al., 2009), mostly through passive resistance, although some also suggested the need for somewhat more active resistance:

[The effect of PM on work motivation] is decreasing, and I have experienced the same effect in the case of my subordinates. For instance, it's humiliating to hear afterwards that your publications aren't consistent with the PM criteria and [are] therefore worth nothing. One must work constantly to psych oneself and others up against this. (2015) 
The Humboldtians' attitude toward IW can be interpreted as maintaining IW (Dansou and Langley, 2012). In line with the findings of Battilana et al. (2009), the projective agency behind IW that aims to maintain institutions is manifested by actions of repairing and defending, typical actions taken by the Humboldtian group. For instance, many Humboldtians explicitly stated that in their work, they tried to maintain the quality of their teaching and research, but PM made it increasingly difficult to do so. Related to teaching quality and external pressure, Gebreiter and Hidayah (2019) studied competing accountability pressures in UK-based business schools, including how individual teachers managed competing institutional demands or commercialization and professionalism. They noted the lecturers' strong sense of professional accountability to the notion of the student as a learner, while feeling heavy pressure related to the customer orientation. They concluded that commercial logic pushed lecturers toward narrow technical content, blackand-white solutions, and a watered-down curriculum. In the future, more lecturers may be tempted to adopt instrumental compliance to student demands. Thus, with the domination of customer accountability measures, the development might lead to prioritizing the users' short-term satisfaction over the organization's long-term effectiveness. Similarly, in our study, given the considerably decreased number of Humboldtians from 2010 to 2015, there may also be fewer scholars who try to maintain the old institution. It will potentially open the door in the future for institutional change in favor of other types of IW, in addition to maintaining institutions (see Battilana et al., 2009). Emphasizing that institutions are products of action, in this case, the Humboldtians' maintaining action fights to keep the old institutions alive (Lawrence and Suddaby, 2006). We suggest explanations for this. First, many Humboldtians might have migrated to the Critical Adaptors' viewpoint. Although some academics might still possess their contrasting view of PM, in order to survive career competition, they need to participate in "playing the game" by the new rules (e.g., survival of the fittest). Second, as older generations of scholars retire or other scholars leave the academic career, emerging scholars might become more indoctrinated in the PM principles (e.g., evolution of views). As stated by Kallio et al. (2016), PM may reinforce the polarization of academic careers.

Of the three main clusters, the Performance Managed cluster had the most positive responses about PM's effects. Many of these respondents regarded it as either a positive or a potentially positive trend in academia. Those who perceived PM in a positive light often underlined their competitive nature and considered PM an opportunity to advance their careers and increase their salaries. Consequently, some attributes discussed above related to business logic (see Figure 1) were clearly visible in the Performance Managed scholars' responses. In particular, extrinsic motivation (especially the motivating effect of salary), increasing value for money, a focus on (quantifiable) outputs, and a competitive ethos were either explicitly or implicitly constantly present in their responses. Numerous respondents suggested that advancing one's career and receiving a salary increase occurred especially as results of publishing articles in prestigious journals. Those who viewed PM as potentially positive typically suggested that it currently had too little effect on their salaries. They complained that as their universities were unable to adequately reward good accomplishments, the PM did not work as it should. The Performance Managed scholars' responses showed many traces of IW, as illustrated in the following extracts:

I have tried to prioritize research and publishing and get rid of the rest (for example, teaching and planning). (2015)

I'm aware of the university's performance measurements, and I know how we are doing at the departmental level. I have also created indicators for myself (and somewhat for others) through which I seek to give a monetary value to different kinds of outputs (publications, theses, degrees, 
AAAJ

34,9

etc.). Through these [indicators], I try to operate in such a manner that, as an individual, I produce more than is invested in me and make the discipline operate in the same way. [. . .]I Iadmit that I follow up the outputs and plan the inputs in publication production and thesis supervision so that they will certainly be productive. (2015)

While generally, the Performance Managed cluster was clearly more positive about PM than the other two main clusters, many of its respondents still saw undesirable side effects of PM. One scholar stated:

Just yesterday, I accepted such a final course attainment for a student who would soon be graduating, which would not have been accepted [i.e., the quality of the attainment was not good enough] in the world before performance measurement. (2010)

Moreover, several scholars complained about the stress caused by PM-related monitoring and the bureaucracy created by the demand for reporting outputs. Compared with Humboldtians, who were deeply committed to professional logic, the Performance Managed cluster seemed to lean on business logic but were less committed to it. Sometimes, they expressed a longing for the times before PM. In their responses, they even exhibited certain attributes of professional logic, especially intrinsic motivation toward academic work. Nevertheless, due to their attitude toward PM, as a group, Performance Managed can be perceived as disrupting professional logic and creating new institutions in academia (Czarniawska, 2009). For instance, by focusing only on the measured attributes of their work, as the respondent above stated, by "prioritizing research and publishing and getting rid of the rest," these academics expressed their IW as undermining institutional mechanisms embedded in professional logic (see Battilana et al., 2009). For some of the Performance Managed respondents, this disruptive IW (Dansou and Langley, 2012) seemed more explicit; for others, it appeared more implicit. Accordingly, both intentional and unintentional disruptive work could be recognized from the responses of the Performance Managed cluster. Moreover, while some Performance Managed respondents seemed to aim to enhance business logic, others - those who simultaneously exhibited characteristics of professional logic enhanced a hybrid logic. Similarly, Pache and Santos (2013) note the persisting assumption among decoupling studies that all organization members adhere to the same logic, which is not correct in the case of our study. Instead, as Pache and Santos (2013) observe, in environments where ILs compete for a long amount of time, organizational coalitions representing competing logics will emerge, making it difficult to assess which institutionalized practices should be protected. This is also imminent in our study, as even Performance Managed - who mostly favored the new business logic - still struggled with some aspects of the new logic, such as the decrease in the quality of academic work.

The third major cluster in our analysis, Critical Adaptors, are theoretically the most intriguing group, since their IW was manifested more implicitly compared with the two groups discussed above. While they were typically almost as critical of PM in academia as Humboldtians, they were less oriented to maintaining IW. Therefore, they attempted to balance between traditional values and the new PM-related values. Thus, they simultaneously exhibited the attributes of both professional and business logics. Here, our results confirm Battilana and Lee's (2014) findings, which suggest that different ILs can be combined in a more robust way and create hybrid logics. Our results also support the findings of Nyland et al. (2017), showing how IW at the individual level leads to the institutionalization of hybrid identities. However, this balancing of Critical Adaptors seems to be a question of utilitarian survival rather than preference, as illustrated by the following extracts:

It's a kick in the ass. There's no alternative; you just have to be productive. So, in a certain sense it motivates, while the counter side is that there's not really time to pay attention to the quality of your research; it's essential to look good on paper. (2015) 
My motivation now focuses on different matters and not necessarily "better" matters. Getting funding and publishing seem to be all that is important. It's really stupid! There's a lot of important work that gets neglected because it isn't "appreciated" and [there's a] rush since there's just not enough time to do everything well. A lousy trend. (2015)

$[\mathrm{PM}]$ directs my research so that it (presumably) benefits me and my career. However, it also has downsides: Research focuses on publishing (especially in the outlets dominated by private publication houses), and this research and the "research credits" it produces leave out the topics that really should be studied. In other words, publication pressure does not direct research in the right direction. [...] Quantity rules, not quality. In the long run, this is not in the best interest of society. In that sense, performance measurement is demotivating. (2015)

For Critical Adaptors, playing by the rules of the game of the PM doctrine can be considered a utilitarian survival strategy in the changing world of academia. Accordingly, an idea was embedded in many responses in this cluster - if they did not adapt their behavior to the new PM-oriented demands, they would jeopardize their careers. The premise was that salaries, promotions, and taking up open positions were increasingly determined by PM-oriented indicators in Finnish academia. In terms of IW, it is difficult to recognize explicit aims in the Critical Adaptors' behavior. Nevertheless, their work's unintentional outcomes (Lawrence et al., 2009, 2013) can have significant disruptive effects from the perspective of traditional professional logic. Despite their reluctance and because of their partial adaptation to playing by the PM rules, they implicitly disrupt traditional professional logic and advance the emergence of new institutions, including through their unintentional IW (Dansou and Langley, 2012). These results are consistent with those of Suddaby et al. (2015) in that the agency constituting IW is not always reflexive (intentional) but can just be habitual.

The new institution that the Critical Adaptors' work unintentionally advances is hybrid logic rather than business logic. Besides being caught between two dominant competing logics, a central feature of hybrid organizations is that the ILs embodied in them are not always compatible; as the degree of this incompatibility increases, the challenges become heightened (Pache and Santos, 2013). Based on our study's data, relying on the competitive logic seems to come at a cost. While numerous respondents in all four clusters stated that pressures and work-related stress had increased due to PM, this was particularly evident in the Critical Adaptors cluster. The experiences of pressure and work-related stress are understandable. The reason is that the situation where highly educated and intelligent individuals adapt to something they consider secondary or even detrimental, as many respondents explicitly stated, can cause cognitive dissonance (see Martin-Sardesai et al., 2017c).

We have analyzed how the three main clusters of our study exhibit IL and how performance-oriented demands are mediated in scholarly work. Our findings are interesting in light of Boitier and Rivière's (2013, p. 642) argument that it is risky to implement PM systems because they could potentially be rejected "by university academic staff whose values may be in contradiction with the strictly managerial approach involved." Although most scholars remain critical of PM systems in universities, they are increasingly adapting to PM systems due to institutional pressures and in particular, utilitarian survival in the changing institutional environment. Borrowing the theme of Coleman's (1986) classic scheme of macro-micro-macro links (Figure 3), we have drawn a "big picture" of our analysis in the form of institutional evolution (cf. Dansou and Langley, 2012). Specifically, microlevel action mediates and transforms macrolevel changes in new institutions.

Previous researchers have suggested that business logic has challenged or even replaced traditional professional logic in various fields (Thornton and Ocasio, 1999; Van Gestel and Teelken, 2006). Our data do not suggest that business logic has replaced
Performance measurement in universities 
AAAJ

34,9

152

professional logic at the microlevel of academia but indicate the former as definitely having challenged the latter. As suggested by Pollitt (2013), competing logics can be related in different ways. In this study, it seems that the PM practices adopted by universities and departments prompt a clash of two distinct competitive logics and advance the emergence of the third-hybrid logic. Traditional professional logic still seems to dominate the microlevel of academia. However, at the macrolevel, business logic has received a significant boost from the government's policies, particularly the Ministry of Education and Culture's funding scheme, which the individual universities and departments have copied in their internal administration (Kallio et al., 2020).

While it seems that these different ILs currently coexist in Finnish academia in competitive, dynamic tension (Pollitt, 2013, p. 347), the overall trend seems to be the hybridization of ILs (Battilana and Lee, 2014). If this trend continues, hybrid logic will be dominant in the future (Figure 3). The hybridization of logics is related to the fact that in their day-to-day work, individual scholars embody characteristics of both professional and business logics (Grossi et al., 2020a). This development is especially associated with the increase in the number of scholars we have labeled as Critical Adaptors and with their disruptive work. They prefer the values of traditional professional logic but have started to increasingly play by the rules of PM to survive in the changing world of academia. This can be considered unintentional disruptive work (cf. Dansou and Langley, 2012).

Our analysis suggests that not all disruptive works are alike. Enabled by directed content analysis (Hsieh and Shannon, 2005), we have further divided disruptive work into two subcategories - intentional (explicit) and unintentional (implicit). We also suggest that both may have the same practical outcome (Suddaby et al., 2015) and may further implicitly foster the emergence of a new IL - hybrid logic in this study. This aligns with the point made by Lawrence et al. (2009, p. 11) that IW aimed at creating institutions "might affect unanticipated institutions in unintended ways, including disrupting those institutions or creating ones very different from those originally conceived of by the actors involved." From the institutional evolution perspective, we suggest that the Critical Adaptors' mostly unintentional disruptive work is a complementary element in the creation of new institutions in academia (cf. Dansou and Langley, 2012).

Figure 3. Institutional evolution and IL and IW in academia
Institutional work

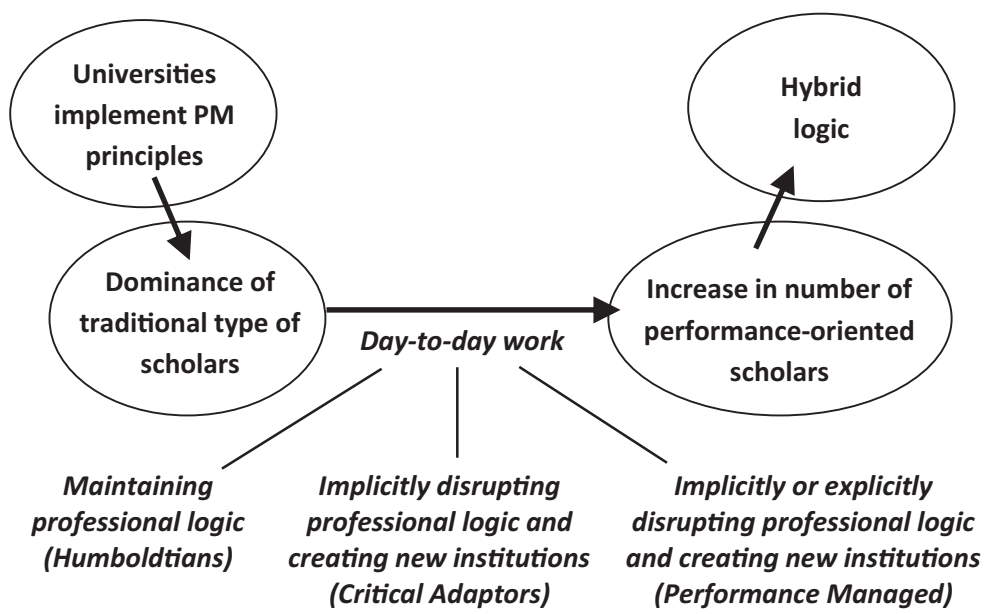




\section{Conclusions}

In the introduction, we presented two research questions:

(1) Do scholars experience a steering effect due to PM, and do they perceive PM as increasing work efficiency in academia?

(2) How does the introduction of PM practices affect IL at the microlevel of academia, and how does scholars' work mediate the performance-oriented demands?

Based on the first question, our quantitative data analysis indicated four distinct clusters of scholars, while our qualitative data analysis pinpointed specific patterns and characteristics of three of them.

The first identified group, Humboldtians, neither believed that PM would increase work efficiency in universities nor thought that PM would steer their work. The qualitative analysis suggests that Humboldtians lean on professional logic and almost unanimously perceive PM as having only negative effects on academia. In contrast, the second group, Performance Managed, believed that PM increased work efficiency in universities and reported its steering effect on their work. While they seemed to lean on business logic, they were less extreme in their opinions than Humboldtians. The qualitative analysis shows that despite being relatively positive about PM in academia, the Performance Managed group often identified problems related to it.

The third group, Critical Adaptors, reported that PM steered their work but, interestingly, disagreed that PM would increase work efficiency in universities. While seemingly contradictory, it can be considered a rational response to the increased pressure in academia caused by PM. However, being a Critical Adaptor does not necessarily mean realizing the best of both worlds; instead, it signifies accepting the necessity of utilitarian survival in the fastchanging world of academia. Based on the qualitative analysis, most Critical Adaptors resembled Humboldtians more than Performance Managed and tended to hold traditional academic values despite having adopted more PM-oriented rationalities. The Critical Adaptors cluster gained a considerable amount of relative weight over the five-year study period (10.07 percentage points) and by far exceeded Performance Managed as the second largest cluster in 2015. Should this trend continue in the future, Performance Managed will surpass Humboldtians as the largest cluster.

Regarding the second question, the PM practices adopted by universities and departments seem to have pushed scholars' move toward business logic, prompting the clash of professional and business logics. This clash has advanced the emergence of a hybrid logic; thus, three competing ILs seem to exist in Finnish academia. Unlike some studies addressing competing ILs (Thornton and Ocasio, 1999; Van Gestel and Teelken, 2006), our study's empirical findings do not suggest that business logic would replace traditional professional logic at the microlevel in Finnish academia. Accordingly, the essential change in this context seems to occur between professional logic and the emerging hybrid logic.

We contribute to the academic debate on IL and IW by showing that Critical Adaptors, positioned somewhere between Humboldtians and Performance Managed, exhibit characteristics of both professional and business logics, thus advancing the emergence of hybrid logic (Battilana and Lee, 2014). Business and professional logics can also coexist in an emerging group of university workers (Critical Adaptors), with different degrees of temporary dominance, in advancing the emergence of hybrid logic. Consequently, although adaptation is, above all, a way to survive for many of them, though their work, Critical Adaptors implicitly disrupt professional logic and create new institutions as unintended outcomes (cf. Lawrence et al., 2009; Martin-Sardesai and Guthrie, 2018). Compared with the case of Performance Managed, this disruption is less intentional and can be considered an 
unintentional IW (Dansou and Langley, 2012; Suddaby et al., 2015). Interestingly, the dayto-day work, the implicit IW, might be the passage toward the new hybrid logic (see Figure 3). Our findings contribute to the scientific debate on individual actors' role in promoting institutional changes in the university field. We show that in Finnish universities, emerging business logics (dominant in the Performance Managed group) and existing traditional professional logics (still dominant among Humboldtians) can also co-exist and be blended (hybrid logic) among a growing group of academics (Critical Adaptors).

A limitation of this study is the difficulty in empirically capturing the reflective purposefulness of IW (Zilber, 2013). Consequently, our study differs from ethnographic studies that can provide comprehensive descriptions of how individual professionals interact with institutions in their day-to-day operations (see McPherson and Sauder, 2013). Our methodological approach directs us to perceive day-to-day operations, not from the perspective of individual scholars, but from that of clusters of scholars.

Despite its limitations, our study provides extensive data that help in understanding the institutional evolution in academia due to PM reform. Our analysis suggests that traditional professional logic remains alive for scholars who want to resist the changes caused by PM (cf. Townley, 1997). In contrast, business logic is available for those who want to use it, for instance, to advance their careers. We can only assume that similar to the expert workers in McPherson and Sauder's (2013) study dealing with a drug court, scholars in academia also apply different logics in different situations. Thus, future research should pay more attention to the unintentional aspect of IW to understand how professionals maintain, disrupt, and create institutions when applying different logics.

\section{Notes}

1. Finland has a long tradition of unions, and tenured employees are protected by industrial relations legislation. However, in the Finnish system, tenure is tied to a position or chair in most universities, since the budgets are traditionally prepared on a preset number of employees in each field or department. This means that unless a chair or position is available, even the most competent professionals cannot be tenured. This also has an effect in that those up for most positions are selected under a highly competitive process. Due to the budget cuts by the Ministry of Education and Culture, Finland has also witnessed a series of layoffs in different universities.

2. On aggregate, about $60 \%$ of the universities' funding comes directly from the state budget. Most of the external funding received by Finnish universities (approximately 60\%) comes from two major state-operated funds - the Academy of Finland and the Finnish Funding Agency for Technology and Innovation.

3. Nyland et al. (2017) show how IW conducted at the individual level leads to the institutionalization of hybrid identities, combining different professional identities, and how such identities influence collective agency at the organizational level. Aleksandrov et al. (2018) show the importance of understanding and managing reflexivity as it shapes the IW by different actors, thus influencing the direction of both the design and the materialization of the accounting experiments.

4. During the first wave of data collection, after the initial email containing the link to the survey, two reminders were sent out to attract more responses. In the second wave, the deadline for answering the survey was extended to gain more responses. Since the survey was only sent out in the Finnish language, it is nor presented here.

5. In addition to collecting the survey data in two waves, we interviewed all administrative managers in all the faculties studied. In the interviews, we aimed to identify what kinds of PM criteria were used in the different departments. Based on the interviews, we conclude that despite some differences in how much and how detailed the PM criteria of the national funding scheme affected the PM criteria for individual employees, the national PM criteria's basic elements were essentially copied in the universities' (and their departments') PM criteria. 
6. In Finland, the academic career path is divided into four phases (from doctoral candidate to full professorship). The professors in Finland (calculated in total man-years) comprised $17.5 \%$, whereas in our sample, the corresponding proportion of professors was a little less than $14 \%$ (man-years were assumed equal for every observation). Therefore, our sample sufficiently represents the overall share of professors and other research and teaching staff.

7. It is widely accepted that universities are loosely coupled organizations (see, e.g., Ouchi, 1979; Czarniawska and Genell, 2002; Owen-Smith, 2001) and that scholars are typically much more committed to their profession and academic ethos than to their employing organizations (Kallio et al., 2016).

8. The extremely short answers contained no essential information in terms of understanding the mechanism by which PM affects scholarly work or the type of IL and IW involved. Typical brief answers were "negative," "no effect," and "I don't know."

\section{References}

Agyemang, G. (2009), "Responsibility and accountability without direct control? Local education authorities and the seeking of influence in the UK schools sector", Accounting, Auditing and Accountability Journal, Vol. 22 No. 5, pp. 762-788.

Agyemang, G. and Broadbent, J. (2015), "Management control systems and research management in universities: an empirical and conceptual exploration", Accounting, Auditing and Accountability Journal, Vol. 28 No. 7, pp. 1018-1046.

Aleksandrov, E. (2020), "Actors' reflexivity and engagement in the formation of new accounting tools during university hybridisation", Qualitative Research in Accounting and Management, Vol. 17 No. 1 , pp. 51-81.

Aleksandrov, E., Bourmistrov, A. and Grossi, G. (2018), "Participatory budgeting as a form of dialogic accounting in Russia: actors' institutional work and reflexivity trap”, Accounting, Auditing and Accountability Journal, Vol. 31 No. 4, pp. 1098-1123.

Argento, D., Dobija, D. and Grossi, G. (2020), "The disillusion of calculative practices in academia", Qualitative Research in Accounting and Management, Vol. 17 No. 1, pp. 1-17.

Baruch, Y. and Holton, B.C. (2008), "Survey response rate levels and trends in organizational research", Human Relations, Vol. 61 No. 8, pp. 1139-1160.

Battilana, J. (2006), “Agency and institutions: the enabling role of individuals' social position", Organization, Vol. 13 No. 5, pp. 653-676.

Battilana, J. and Lee, M. (2014), "Advancing research on hybrid organizing: insights from the study of social enterprises”, Academy of Management Annals, Vol. 8 No. 1, pp. 397-441.

Battilana, J., D'Aunno, T. and Lawrence, T. (2009), "Institutional work and the paradox of embedded agency", in Suddaby, R. and Leca, B. (Eds), Institutional Work: Actors and Agency in Institutional Studies of Organizations, Cambridge University Press, Cambridge, pp. 31-58.

Besharov, M.L. and Smith, W.K. (2014), "Multiple institutional logics in organizations: explaining their varied nature and implications", Academy of Management Review, Vol. 39 No. 3, pp. 364-381.

Boitier, M. and Riviere, A. (2013), "Freedom and responsibility for French universities: from global steering to local government", Accounting, Auditing and Accountability Journal, Vol. 26 No. 4, pp. 616-649.

Cai, Y. and Mehari, Y. (2015), "The use of institutional theory in higher education research", in Huisman, J. and Tight, M. (Eds), Theory and Method in Higher Education Research, Emerald Group Publishing Limited Vol. 1, pp. 1-25.

Chandler, J., Barry, J. and Clark, H. (2002), "Stressing academe: the wear and tear of the new public management”, Human Relations, Vol. 55 No. 9, pp. 1051-1069. 
Chatterjee, B., Cordery, C.J., De Loo, I. and Letiche, H. (2020), "The spectacle of research assessment systems: insights from New Zealand and the United Kingdom”, Accounting, Auditing and Accountability Journal, Vol. 33 No. 6, pp. 1219-1246.

Christopher, J. (2012), "Tension between the corporate and collegial cultures of Australian public universities: the current status", Critical Perspectives on Accounting, Vol. 23 No. 78, pp. 556-571.

Churchman, D. (2002), "Voices of the academy: academic' responses to the corporatizing of academia", Critical Perspectives on Accounting, Vol. 13 Nos 5/6, pp. 643-656.

Coleman, J.S. (1986), "Social theory, social research, and a theory of action", The American Journal of Sociology, Vol. 91 No. 6, pp. 1309-1335.

Conrath-Hargreaves, A. and Wüstemann, S. (2019), "Multiple institutional logics and their impact on accounting in higher education: the case of a German foundation university", Accounting, Auditing and Accountability Journal, Vol. 32 No. 3, pp. 782-810.

Czarniawska, B. (2009), "Emerging institutions: pyramids or anthills?", Organization Studies, Vol. 30 No. 4, pp. 423-441.

Czarniawska, B. and Genell, K. (2002), "Gone shopping? Universities on their way to the market", Scandinavian Journal of Management, Vol. 18 No. 4, pp. 455-474.

Dansou, K. and Langley, A. (2012), "Institutional work and the notion of test”, M@n@gement, Vol.15 No. 5 , pp. 502-527.

Dobija, D., Górska, A.M., Grossi, G. and Strzelczyk, W. (2019), "'Rational and symbolic uses of performance measurement: experiences from Polish universities", Accounting, Auditing \& Accountability Journal, Vol. 32 No. 3, pp. 750-781.

Englund, H. and Gerdin, J. (2019), "Contesting conformity: how and why academics may oppose the conforming influences of intra-organizational performance evaluations", Accounting, Auditing and Accountability Journal, Vol. 33 No. 5, pp. 913-938.

Gawer, A. and Phillips, N. (2013), "Institutional work as logics shift: the case of Intel's transformation to platform leader", Organization Studies, Vol. 34 No. 8, pp. 1035-1071.

Gebreiter, F. (2021), "A profession in peril? University corporatization, performance measurement and the sustainability of accounting academia", Critical Perspectives on Accounting. doi: 10.1016/j. cpa.2021.102292.

Gebreiter, F. and Hidayah, N.N. (2019), "Individual responses to competing accountability pressures in hybrid organisations: the case of an English business school", Accounting, Auditing and Accountability Journal, Vol. 3 No. 3, pp. 727-749.

Graneheim, U.H. and Lundman, B. (2004), "Qualitative content analysis in nursing research: concepts, procedures and measures to achieve trustworthiness", Nurse Education Today, Vol. 24 No. 2, pp. 105-112.

Greenwood, R., Suddaby, R. and Hinings, C.R. (2002), "Theorizing change: the role of professional associations in the transformation of institutional fields", Academy of Management Journal, Vol. 45 No. 1, pp. 58-80.

Grossi, G., Dobija, D. and Strzelczyk, W. (2020a), "The impact of institutional pressures and logics on the use of performance measurement practices in hybrid universities", Public Performance Management Review, Vol. 4 No. 4, pp. 818-844.

Grossi, G., Kallio, K.M., Sargiacomo, M. and Skoog, M. (2020b), "Accounting, performance management systems, and accountability changes in knowledge-intensive public organizations: a literature review and research agenda", Accounting, Auditing and Accountability Journal, Vol. 33 No. 1, pp. 256-280.

Gumport, P.J. (2000), "Academic restructuring: organizational change and institutional imperatives", Higher Education, Vol. 39 No. 1, pp. 67-91.

Guthrie, J. and Neumann, R. (2007), "Economic and non-financial performance indicators in universities", Public Management Review, Vol. 9 No. 2, pp. 231-252. 
Guthrie, J., Evans, E. and Burritt, R. (2014), "Australian accounting academics: challenges and possibilities”, Meditari Accountancy Research, Vol. 22 No. 1, pp. 20-37.

Hood, C. (1995), "The 'new public management' in the 1980s: variations on a theme", Accounting, Organizations and Society, Vol. 20 Nos 2/3, pp. 93-109.

Hsieh, H.F. and Shannon, S.E. (2005), “Three approaches to qualitative content analysis”, Qualitative Health Research, Vol. 15 No. 9, pp. 1277-1288.

Järvenpää, M., Kallio, K.-M., Kallio, T.J. and Rautainen, A. (2021), "The chain of control in resultsbased management in Finnish universities", in Hoque, Z. (Ed.), Public Sector Reform and Performance Management in Developed Economies: Outcomes-Based Approaches in Practice, Routledge, London and NY, pp. 177-192.

Kallio, K.-M. and Kallio, T.J. (2014), "Management-by-results and performance measurement in universities-implications for work motivation”, Studies in Higher Education, Vol. 39 No. 4, pp. 574-589.

Kallio, K.-M., Kallio, T.J., Tienari, J. and Hyvönen, T. (2016), "Ethos at stake: performance management and academic work in universities", Human Relations, Vol. 69 No. 3, pp. 685-709.

Kallio, K.-M., Kallio, T.J. and Grossi, G. (2017), "Performance measurement in universities: ambiguities in the use of quality versus quantity in performance indicators", Public Money \& Management, Vol. 37 No. 4, pp. 293-300.

Kallio, T.J., Kallio, K.-M. and Blomberg, A. (2020), "From professional bureaucracy to competitive bureaucracy - redefining universities' organizational principles, performance measurement criteria, and reason for being", Qualitative Research in Accounting and Management, Vol. 17 No. 1, pp. 82-108.

Kallunki, J., Kivistö, J. and Kohtamäki, V. (2019), "Funding of higher education (Finland)", in Kauko, J. and Jacob, J. (Eds), Bloomsbury Education and Childhood Studies, Bloomsbury Academic.

Lawrence, T.B. and Suddaby, R. (2006), "Institutions and institutional work", in Clegg, S.R., Hardy, C., Lawrence, T.B. and Nord, W.R. (Eds), Handbook of Organization Studies, 2nd edn, SAGE Publications Inc., London, pp. 215-254.

Lawrence, T.B., Suddaby, R. and Leca, B. (2009), "Introduction: theorizing and studying institutional work", in Lawrence, T.B., Suddaby, R. and Leca, B. (Eds), Institutional Work: Actors and Agency in Institutional Studies of Organizations, Cambridge University Press, Cambridge, pp. 1-27.

Lawrence, T., Suddaby, R. and Leca, B. (2011), "Institutional work: refocusing institutional studies of organization", Journal of Management Inquiry, Vol. 20 No. 1, pp. 52-58.

Lawrence, T.B., Leca, B. and Zilber, T.B. (2013), "Institutional work: current research, new directions and overlooked issues”, Organization Studies, Vol. 34 No. 8, pp. 1023-1033.

Lepori, B. and Montauti, M. (2020), "Bringing the organization back in: flexing structural responses to competing logics in budgeting", Accounting, Organizations and Society, Vol. 80, doi: 10.1016/j. aos.2019.101075.

Lounsbury, M. (2008), "Institutional rationality and practice variation: new directions in the institutional analysis of practice", Accounting, Organisations and Society, Vol. 33 Nos 4/5, pp. 349-361.

Martin-Sardesai, A. and Guthrie, J. (2018), "Human capital loss in an academic performance measurement system", Journal of Intellectual Capital, Vol. 19 No. 1, pp. 53-70.

Martin-Sardesai, A., Irvine, H., Tooley, S. and Guthrie, J. (2017a), "Organizational change in an Australian university: responses to a research assessment exercise", The British Accounting Review, Vol. 49 No. 4, pp. 399-412.

Martin-Sardesai, A., Irvine, H., Tooley, S. and Guthrie, J. (2017b), "Government research evaluations and academic freedom: a UK and Australian comparison", Higher Education Research and Development, Vol. 36 No. 2, pp. 372-385. 
AAAJ 34,9

Martin-Sardesai, A., Irvine, H., Tooley, S. and Guthrie, J. (2017c), “Accounting for research: academic responses to research performance demands in an Australian university", Australian Accounting Review, Vol. 27 No. 82, pp. 329-343.

Martin-Sardesai, A., Guthrie, J., Tooley, S. and Chaplin, S. (2019), "History of research performance measurement systems in the Australian higher education sector", Accounting History, Vol. 24 No. 1, pp. 40-61.

Martin-Sardesai, A., Guthrie, J. and Tucker, B.P. (2020), "What you see depends on where you look: performance measurement of Australian accounting academics", Accounting, Auditing and Accountability Journal. doi: 10.1108/AAAJ-08-2019-4133.

McInnis, C. (2010), "Traditions of academic professionalism and shifting academic identities", in Gordon, G. and Whitchurch, C. (Eds), Academic and Professional Identities in Higher Education: The Challenges of a Diversifying Workforce, Routledge, London, pp. 147-165.

McPherson, C.M. and Sauder, M. (2013), "Logics in action: managing institutional complexity in a drug court”, Administrative Science Quarterly, Vol. 58 No. 2, pp. 165-196.

Mkasiwa, T.A. (2020), "Budgetary practices in a Tanzanian University: bourdieu's theory", Journal of Public Budgeting, Accounting and Financial Management, Vol. 32 No. 3, pp. 399-420.

Modell, S. (2005), "Students as consumers? An institutional field-level analysis of the construction of performance measurement practices", Accounting, Auditing and Accountability Journal, Vol. 18 No. 4, pp. 537-563.

Modell, S. (2020), “Accounting for institutional work: a critical review”, European Accounting Review. doi: 10.1080/09638180.2020.1820354.

Moll, J. and Hoque, Z. (2011), "Budgeting for legitimacy: the case of an Australian university", Accounting, Organizations and Society, Vol. 36 No. 2, pp. 86-101.

Narayan, A., Northcott, D. and Parker, L.D. (2017), "Managing the accountability-autonomy tensions in university research commercialisation", Financial Accountability and Management, Vol. 33 No. 4, pp. 335-355.

Nyland, K., Morland, C. and Burns, J. (2017), "The interplay of managerial and non-managerial controls, institutional work, and the coordination of laterally dependent hospital activities", Qualitative Research in Accounting and Management, Vol. 14 No. 4, pp. 467-495.

Ouchi, W.G. (1979), "A conceptual framework for the design of organizational control mechanisms", Management Science, Vol. 25 No. 9, pp. 833-848.

Owen-Smith, J. (2001), "Managing laboratory work through skepticism: processes of evaluation and control", American Sociological Review, Vol. 66 No. 3, pp. 427-452.

O'Connell, B., De Lange, P., Stoner, G. and Sangster, A. (2020a), "Impact of research assessment exercises on research approaches and foci of accounting disciplines in Australia", Accounting, Auditing and Accountability Journal, Vol. 33 No. 6, pp. 1277-1302.

O'Connell, B., De Lange, P., Martin-Sardesai, A. and Agyemang, G. (2020b), “'Measurement and assessment of accounting research, impact and engagement”, Accounting, Auditing \& Accountability Journal, Vol. 33 No. 6, pp. 1177-1192.

Pache, A.-C. and Santos, F. (2013), "Inside the hybrid organization: selective coupling as a response to competing institutional logics", Academy of Management Journal, Vol. 56 No. 4, pp. 972-1001.

Parker, L.D. (2011), "University corporatization: driving redefinition", Critical Perspectives on Accounting, Vol. 22 No. 4, pp. 434-450.

Parker, L.D. (2012), "From privatized to hybrid corporatized higher education: a global financial management discourse”, Financial Accountability and Management, Vol. 28 No. 3, pp. 247-268.

Parker, M. (2014), "University, Ltd: changing a business school", Organization, Vol. 21 No. 2, pp. 281-292. 
Parker, L. and Guthrie, J. (2010), "Business schools in an age of globalization", Accounting, Auditing and Accountability Journal, Vol. 23 No. 1, pp. 5-13.

Pollitt, C. (2013), "The logics of performance management", Evaluation, Vol. 19 No. 4, pp. 346-363.

Roberts, R.W. (2004), "Managerialism in US universities: implications for the academic accounting profession”, Critical Perspectives on Accounting, Vols 15 Nos 4-5, pp. 461-467.

Shih, T. and Fan, X. (2009), "Comparing response rates in e-mail and paper surveys: a meta-analysis", Educational Research Review, Vol. 4 No. 11, pp. 26-40.

Steccolini, I., Saliterer, I. and Guthrie, J. (2020), "The role(s) of accounting and performance measurement systems in contemporary public administration", Public Administration, Vol. 98, pp. 3-13.

Suddaby, R., Saxton, G.D. and Gunz, S. (2015), "Twittering change: the institutional work of domain change in accounting expertise", Accounting, Organizations and Society, Vol. 45 No. C, pp. 52-68.

Suomi, K., Kuoppakangas, P., Hytti, U., Hampden-Turner, C. and Kangaslahti, J. (2014), "Focusing on dilemmas challenging reputation management in higher education", International Journal of Educational Management, Vol. 28 No. 4, pp. 461-478.

Ter Bogt, H. and Scapens, R. (2012), "Performance management in universities: effects of the transition to more quantitative measurement systems”, European Accounting Review, Vol. 21 No. 3, pp. 451-497.

Thornton, P.H. and Ocasio, W. (1999), "Institutional logics and the historical contingency of power in organizations: executive succession in the higher education publishing industry, 1958-1990", American Journal of Sociology, Vol. 105 No. 3, pp. 801-843.

Thornton, P.H. and Ocasio, W. (2008), "Institutional logics", in Greenwood, R., Oliver, C., Sahlin, K. and Suddaby, R. (Eds), The Sage Handbook of Organizational Institutionalism, SAGE Publications, London, pp. 99-129.

Thornton, P.H., Jones, C. and Kury, K. (2005), "Institutional logics and institutional change in organizations: transformation in accounting, architecture, and publishing", Research in the Sociology of Organizations, Vol. 23, pp. 125-170.

Thornton, P.H., Ocasio, W. and Lounsbury, M. (2012), The Institutional Logics Perspective: A New Approach to Culture, Structure and Process, Oxford University Press, Oxford.

Townley, B. (1997), "The institutional logic of performance appraisal", Organization Studies, Vol. 18 No. 2, pp. 261-285.

Tucker, B.P. and Parker, L.D. (2020), "The question of research relevance: a university management perspective", Accounting, Auditing and Accountability Journal, Vol. 33 No. 6, pp. 1247-1275.

Upping, P. and Oliver, J. (2012), "Thai public universities: modernisation of accounting practices", Journal of Accounting and Organizational Change, Vol. 8 No. 3, pp. 403-430.

Van Gestel, N. and Teelken, C. (2006), "Neo-institutional perspectives on public management reform", Management International, Vol. 10 No. 3, pp. 99-109.

Zilber, T.B. (2013), "Institutional logics and institutional work: should they be agreed?", Research in the Sociology of Organizations, Vol. 39, pp. 77-96.
Performance measurement in universities 


$\begin{array}{ll}\text { AAAJ } & \text { Appendix } \\ 34,9 & \end{array}$

Table A1.

Cross-tabulations; 2010 percentages above and 2015

percentages below

\begin{tabular}{|c|c|c|c|c|c|c|}
\hline \multicolumn{7}{|c|}{ PM increases work efficiency in universities } \\
\hline $\begin{array}{r}\text { PM steers my } \\
\text { work }\end{array}$ & $\begin{array}{c}\text { Completely } \\
\text { agree (\%) }\end{array}$ & $\begin{array}{l}\text { Mostly } \\
\text { agree (\%) }\end{array}$ & $\begin{array}{c}\text { Do not } \\
\text { agree or } \\
\text { disagree (\%) }\end{array}$ & $\begin{array}{c}\text { Mostly } \\
\text { disagree (\%) }\end{array}$ & $\begin{array}{c}\text { Completely } \\
\text { disagree (\%) }\end{array}$ & Total (\%) \\
\hline Completely & 1.11 & 1.11 & 0.77 & 0.88 & 1.33 & 5.20 \\
\hline agree & 1.85 & 2.01 & 0.93 & 2.16 & 0.93 & 7.87 \\
\hline Mostly agree & 0.77 & 9.18 & 5.09 & 5.64 & 2.65 & 23.34 \\
\hline \multirow{3}{*}{$\begin{array}{r}\text { Do not agree or } \\
\text { disagree }\end{array}$} & 0.93 & 10.96 & 6.94 & 11.42 & 4.48 & 34.72 \\
\hline & 0.22 & 4.42 & 9.29 & 7.63 & 5.31 & 26.88 \\
\hline & 0.15 & 2.62 & 5.56 & 5.25 & 2.78 & 16.36 \\
\hline Mostly disagree & 0.11 & 2.10 & 2.77 & 8.52 & 6.42 & 19.91 \\
\hline \multirow{3}{*}{$\begin{array}{r}\text { Completely } \\
\text { disagree }\end{array}$} & 0.00 & 2.01 & 4.17 & 8.95 & 6.94 & 22.07 \\
\hline & 0.33 & 0.55 & 2.77 & 3.87 & 17.15 & 24.67 \\
\hline & 0.00 & 0.62 & 1.54 & 4.17 & 12.65 & 18.98 \\
\hline \multirow[t]{2}{*}{ Total } & 2.54 & 17.37 & 20.69 & 26.55 & 32.85 & 100 \\
\hline & 2.93 & 18.21 & 19.14 & 31.94 & 27.78 & 100 \\
\hline \multicolumn{7}{|c|}{2010 Frequency missing $=8.07 \% ; 2015$ Frequency missing $=3.57 \%$} \\
\hline
\end{tabular}

Table A2.

\begin{tabular}{llccc}
\hline Characteristics & & $2010(\%)$ & $2015(\%)$ & Difference (\% points) \\
\hline \multirow{2}{*}{ Gender } & Male & 53.9 & 49.9 & -4.0 \\
& Female & 46.1 & 50.2 & +4.0 \\
Faculty & Education Sciences & 15.4 & 16.2 & +0.8 \\
& Business and Economics & 45.7 & 39.8 & -5.9 \\
& Natural Sciences & 15.2 & 14.7 & -0.5 \\
Work experience (years) & Humanities & 23.6 & 29.4 & +5.8 \\
& -5 & 20.7 & 14.5 & $-6.2^{*}$ \\
& $5-10$ & 25.0 & 19.8 & -5.2 \\
& $11-20$ & 27.4 & 34.4 & +7.0 \\
Group of profession & $21-30$ & 14.4 & 19.2 & +4.8 \\
& $>30$ & 12.5 & 12.3 & -0.2 \\
& Professor & 16.7 & 18.7 & +2.0 \\
& Lecturer & 51.4 & 49.8 & -1.6 \\
Sample size & Researcher & 25.7 & 28.3 & +2.6 \\
Note(s): $* p<0.05$ & Other & 6.3 & 3.2 & -3.1 \\
& - & 966 & 672 & \\
& & & &
\end{tabular}

Differences in characteristics of respondents in 2010

Note(s): $* p<0.05$

Male

Business and Economics

Natural Sciences

$<5$

21-30

Professor

Lecturer

Researcher

Other

About the authors

Kirsi-Mari Kallio is a Professor of Accounting and Finance at Turku School of Economics at the University of Turku, Finland as well as visiting associate professor at Linnaeus University, Sweden. Her research interests include performance management in knowledge-intensive organizations, especially in 
the context of university organizations. She has published in interdisciplinary journals, such as Human Relations, Studies in Higher Education, Accounting, Auditing \& Accountability Journal, Qualitative Research in Accounting \& Management, and Public Money \& Management. Kirsi-Mari Kallio is the corresponding author and can be contacted at: kirsi-mari.kallio@utu.fi

Tomi J. Kallio currently works at Turku School of Economics at the University of Turku, Finland. He is also an affiliated professor at Linnaeus University, Sweden. He holds PhDs both in Administrative Science (University of Tampere) and in Business Economics (Turku School of Economics). His research and teaching interests include organizational theory, performance management, knowledge-intensive organizations, organizational creativity and research methodology. He has published in journals such as in universities Human Relations, Studies in Higher Education, Policy Studies, Facilities, Journal of Business Ethics, and Culture and Organization.

Giuseppe Grossi is Research Professor at Nord University, Norway, as well as Professor of Public Management and Accounting at Kristianstad University, Sweden. He is also acting as visiting research professor in Accounting at Kozminski University, Poland. His research focuses on management control practices in organizations, with particular interests in public sector organizations and hybrid organizations. His publications have appeared in several accounting and public management journals.

Janne Engblom is a Senior lecturer of Statistics at Turku School of Economics at University of Turku. His research interests include applications of statistical analysis in management and economics, especially multivariate methods of survey data. He has worked with several research groups and published in journals such as International Review of Retail, Distribution and Consumer Research, Urban Studies and International Journal of Production Economics.

For instructions on how to order reprints of this article, please visit our website: www.emeraldgrouppublishing.com/licensing/reprints.htm Or contact us for further details: permissions@emeraldinsight.com 